\title{
Comments on the selection of effect model and effect size in a meta-analysis
}

\author{
Jiangfeng Wu^, Anli Zhao, Lifang Ge \\ Department of Ultrasound, The Affiliated Dongyang Hospital of Wenzhou Medical University, Dongyang, China \\ Correspondence to: Jiangfeng Wu. Department of Ultrasound, The Affiliated Dongyang Hospital of Wenzhou Medical University, No. 60 Wuning \\ West Road, Dongyang, 322100, Zhejiang, China. Email: wjfhospital@163.com.
}

Submitted Dec 05, 2021. Accepted for publication Jan 30, 2022.

doi: 10.21037/jgo-21-853

View this article at: https://dx.doi.org/10.21037/jgo-21-853

We read with great interest the recent published study by Wang and colleagues entitled "Correlation of ulcerative colitis (UC) and colorectal cancer (CRC): a systematic review and meta-analysis" (1). They performed a systematic review and meta-analysis to explore the specific mechanism of UC influence on CRC and confirmed that the duration, location, and geographical location affect the occurrence of $\mathrm{CRC}$ and are important risk factors for occurrence of CRC in patients with UC. We appreciate Wang and colleagues for the valuable study, however, after a careful learning of the literature, we would like to pay attention to some important missing aspects in the study.

First, concerning the effect size in the study, the risk ratio (RR) was used when the number of patients with UC which progressed to CRC was compared between experimental group and control group. However, in the statistical analysis section of the article, the odds ratio (OR) was introduced as effect size, which was not consistent with RR reported in the main text.

Second, as the eleven studies included in the heterogeneity evaluation revealed significant heterogeneity $(\mathrm{Z}=47.86, \mathrm{P}<0.00001)$, the random-effects model should be selected (2), while the authors actually used a fixed-effects model showed in Figure 4. Because of the remarkable heterogeneity, meta-regression and subgroup analyses should be carried out to explore sources of heterogeneity. The covariates such as country, year of publication, and sample size might be considered.

Finally, there were eleven studies included in this study, whereas, only ten studies were enrolled in this meta-analysis showed in Figure 4. We believe that this study should be further revised to validate the conclusions.

\section{Acknowledgments}

Funding: None.

\section{Footnote}

Provenance and Peer Review: This article was a standard submission to the journal. The article did not undergo external peer review.

Conflicts of Interest: All authors have completed the ICMJE uniform disclosure form (available at https://jgo.amegroups. com/article/view/10.21037/jgo-21-853/coif). The authors have no conflicts of interest to declare.

Ethical Statement: The authors are accountable for all aspects of the work in ensuring that questions related to the accuracy or integrity of any part of the work are appropriately investigated and resolved.

Open Access Statement: This is an Open Access article distributed in accordance with the Creative Commons Attribution-NonCommercial-NoDerivs 4.0 International License (CC BY-NC-ND 4.0), which permits the noncommercial replication and distribution of the article with the strict proviso that no changes or edits are made and the original work is properly cited (including links to both the

^ ORCID: 0000-0002-5036-799X. 
formal publication through the relevant DOI and the license). See: https://creativecommons.org/licenses/by-nc-nd/4.0/.

\section{References}

1. Wang Y, Wang P, Shao L. Correlation of ulcerative colitis and colorectal cancer: a systematic review and meta-

Cite this article as: $\mathrm{Wu} \mathrm{J}$, Zhao A, Ge L. Comments on the selection of effect model and effect size in a meta-analysis. J Gastrointest Oncol 2022;13(1):450-451. doi: 10.21037/jgo-21-853 analysis. J Gastrointest Oncol 2021. doi: 10.21037/jgo21-624.

2. Wu J, Wang Y, Wang Z. The diagnostic accuracy of ultrasound in the detection of foot and ankle fractures: a systematic review and meta-analysis. Med Ultrason 2021;23:203-12. 